\title{
The European Union's Human Rights Policy: Is the EU's use of the Human Rights Clause Inconsistent?
}

Johanne Døhlie Saltnes

\begin{abstract}
Recurrent claims of selective and inconsistent implementation of the EU's human rights clause questions the legitimacy basis of the Union's human rights policy. If the EU's actions does not match its rhetoric, it runs the risk of being accused of hypocrisy. This article contributes with novel empirical insights regarding the question of whether the EU delivers on its human rights policy. When assessing the EU's use of the human rights clause scholarly literature has largely followed rationalist theory arguing that the EU's foreign policy decisions are driven by economic interest or security considerations. I find that existing studies have used a biased selection of cases. A combination of theoretical assumptions and methodological choices appears to be guiding the selection process. Existing hypotheses are not sought falsified, as they are tested only on a set of cases where 'interest' of some sort is already known to exist. I find non-implementation of the clause also in countries where the EU has no such specific 'interests'. Given these additional cases the account of the EU's policy must be reconsidered.
\end{abstract}

\section{Keywords}

Human Rights; Conditionality; Sanctions; Legitimacy; EU-ACP relations; EU foreign policy 


\section{Introduction}

In 1995, the European Union (EU) decided that it would include a human rights clause in all of its cooperation agreements with non-EU countries, making these agreements dependent on the respect for human rights, democracy and good governance. Although this indicates a clear prioritisation of human rights in its foreign policy, the EU has been accused of being "selective and inconsistent" in its implementation of the clause (Crawford, 2000, p. 240; Fierro, 2003). Overall, the literature holds that the EU puts its own interests first so that norms are sidestepped if respecting them involves costs. In addition, the perceived use of double standards by the EU is a central finding by authors investigating external perceptions of the EU's foreign policy (Fioramonti and Poletti, 2008). Policies promoting human rights are accordingly assumed to be simply rhetoric, disguising the "real" objectives of national interest (Schimmelfennig, 2001). Inconsistencies in the use of economic sanctions questions the legitimacy basis of the EU's foreign policy. In accordance with the definition presented in the introduction to this collection output legitimacy is grounded in the "effectiveness, credibility, coherence and success of foreign policy" in the eyes of both internal and external actors. Legitimacy is tied to the extent to which an actor's policy have "delivered on widely-sought goals" (Raube and Tonra this volume). Therefore, inconsistent sanctioning of human rights breaches abroad questions the extent to which the EU is conducting a legitimate human rights policy.

Some observations, however, suggest that this standard interpretation of the EU's behaviour is incorrect. For example, the EU cut aid to Nigeria following irregularities in the 1993 elections (EPC Bulletin, 1993, p. 364). It also adopted new sanctions in 1995 following the controversial trial and public execution of nine environmental activists (Council, 1995). Thus, even though Nigeria is considered to be of economic importance to the EU on account of its oil exports, sanctions were implemented after breaches of both democratic and human rights principles. 
Moreover, Niger - a country that is considered to be of key economic and strategic interest to France has been targeted with the human rights clause four times.

The above examples suggest that there is a need to reassess "accepted truths" in the conditionality literature. In the following, I re-examine the empirical basis of earlier studies, and identify the existence of a selection bias in the literature on the human rights clause. This bias concerns the so-called non-cases - that is, cases where punitive measures were not imposed even though breaches of the human rights clause have occurred. In the literature only non-cases where 'interest' of some sort is already known to exist are examined, thus the research design does not allow for falsifiable hypotheses. Alongside the examples used in the existing literature, I find numerous instances of such non-cases where no clear economic or strategic interest could be identified. Therefore, there is a need for systematic empirical scrutiny of the evidence provided in the literature and to further explore alternative hypotheses. To make a reasonable assessment of the EU's conditionality policy we first need to reconsider the EU's actual practice of the human rights clause.

\section{Domination of Interest-Driven Perspectives}

\section{The Primacy of ... Economic Interests?}

The human rights clause has been included in a number of broad cooperation agreements regulating trade between the EU and non-EU states. ${ }^{1}$ In the literature it is often asserted that possible economic gains through trade will tend to trump normative foreign policy objectives, and that this in turn can explain the variance we find in the record of implementation of political conditionality. Several contributions argue that poorer and smaller states are more likely to be targeted with sanctions than bigger and richer states. This argument is made by showing that

\footnotetext{
${ }^{1}$ So far only Article 96 of the Cotonou-agreement between the EU and Africa, Caribbean and Pacific (ACP) group of states, has been implemented.
} 
political conditionality has been implemented more often against countries from sub-Saharan Africa than against countries from other regions (Crawford, 1997, 2000; Smith, 1998; Uvin, 2004). However, while sub-Saharan countries are generally poorer than countries from other regions of the world, this is not sufficient in itself to establish a causal relationship between the EU's economic interest in a target state and the likelihood that conditionality will be implemented in the event of a breach of the EU's human rights clause. The fact that poorer countries are more often targeted with sanctions could also be explained by the spurious effect of democratization or human rights violations taking place more frequently in these states. The implicit expectation of self-interest governing the choice of sanctions seems to lead the above studies to conclude without taking alternative accounts into consideration.

Furthermore, studies present conflicting results on the importance of economic interest. On the one hand some studies confirm rationalist expectations. Using the case of Nigeria, for example, it has been claimed that the EU's economic interests accounted for the late implementation of sanctions, as well as the absence of hard sanctions such as an oil embargo in the early 1990s (Arts, 2000; Crawford, 1997, 2000; Smith, 1998; Tomaševski, 1997). The same explanation is used with regard to the non-implementation of the human rights clause after fraudulent elections in Nigeria in 2003 and 2007 (Del Biondo, 2011; Meyer-Resende, 2008). Yet, the EU has not refrained from implementing sanctions against Nigeria. Aid was suspended in 1993 owing to irregularities in the electoral process, and sanctions were renewed in 1995 following the execution of nine environmental activists (Council, 1995; EPC Bulletin, 1993). Furthermore, the sanctions were not lifted until Nigeria's return to a democratically elected government in 1999 (Council, 1999). On the other hand, some studies refute the economic interest hypotheses. Warkotsch (2010) finds that he cannot confirm a general pattern of human rights and democracy interests being subordinate to material interests, although it may be correct for cases where huge economic stakes are involved. In addition, del Biondo (2015) points to the implementation of 
art. 96 towards Niger despite strong French commercial interests in the country. Thus, although much of the literature correctly identify the EU's economic interests in some countries it cannot be concluded that non-implementation of the human rights cause or other sanctions can explained in terms of concern for the costs involved.

\section{... Security Considerations?}

A second strand of hypotheses is linked to the argument of security interests. A first hypothesis concerns the reluctance of donors to impose sanctions upon a state with a putatively important position in relation to other states. A stable country in an otherwise unstable region, for example, may be treated by donors as an ally because of its position vis-à-vis its neighbours. Here, reference is often made to the case of Ethiopia, which is generally viewed as a stable country within the Horn of Africa and an ally of the USA in the "fight against terror" (Brüne, 2007; Jünemann and Knodt, 2007; Meyer-Resende, 2008). Del Biondo (2011, p. 386) argues that security interests account for the lack of implementation of the human rights clause in relation to Nigeria, Ethiopia and Kenya, as these countries are considered key partners of the West in the fight against terrorism and play an important role in maintaining peace in their respective regions. Again, however, these authors' conclusions appear to be grounded in an implicit expectation of interest-based behaviour, without explicitly accounting for the theoretical mechanisms that supposedly trigger particular forms of behaviour. Thus, while the identification of existing security interests may be correct, the hypothesis is not sought falsified since it is tested only against cases where the existence of such interest is already known to exist. $^{2}$

Second, various contributions argue that variation in the use of conditionality can be explained in terms of the colliding foreign policy objectives of security and democracy promotion

\footnotetext{
${ }^{2}$ With the notable exception of Del Biondo (2011) who also investigates Rwanda. See below.
} 
(Crawford, 2000; Olsen, 1998, 2000, 2002a, b; Santiso, 2003). This claim reminds us of the hypothesis forwarded by structural realists according to which normative ideas stop determining policy when they conflict with vital national or common interests (Hyde-Price, 2008; Mearsheimer, 2005). Crawford and Kacarska (2017) argue that the key factor explaining inconsistencies in the use of aid suspensions has shifted from economic interests to security issues. Nevertheless, once again, the relevant articles are based only on the identification of security concerns in a limited selection of cases, which raises questions regarding their validity. For example, had they considered the case Niger they would not have found support for this hypothesis. France has both commercial and security interests in Niger, inter alia to safeguard the supply of Nigerien uranium which supplies 58 French nuclear reactors (del Biondo 2015; Meyer 2010). This has not prevented Niger from being subjected to the conditionality clause. Actually, Niger is the county that most frequently has been targeted with the conditionality clause, namely four times.

\section{Special Relationships}

Another class of arguments suggests that negative measures will be less frequent towards countries that have a "special relationship" with donors. The combination of close bilateral relations and the absence of negative measures has been labelled the "foreign policy paradox" (Feliu, 2003, p. 92), the implication being that the closer the relations between a donor state and a recipient state, the larger the possibility for influence, with a correspondingly reduced risk that the donor state will adopt punitive measures. In the relevant literature, however, no attempt is made to specify when or under what conditions this paradox occurs, or indeed to define what might constitute a "special relationship". This term is insufficiently specified to stand out as a clear analytical category. Smith (1998: 273) holds that following violations of democratic principles in Cameroon, sanctions were blocked by France because the African state was within France's "sphere of influence". Seen in a historical context, it has been argued that former 
colonial powers - especially France - are more reluctant to impose punitive sanctions in cases involving their own former colonies (Alesina and Dollar, 2000; Olsen, 1998; Stokke, 1995). Two questions arise: What are the main elements that define the nature of a "special relationship"? And, when is such a relationship considered sufficiently strong to account for the alleged behaviour? The empirical record shows conflicting results: Jünemann and Knodt (2007: 354) find the foreign policy paradox to be significant in the EU's relations with northern Africa but not in its relations with sub-Saharan Africa, while Warkotsch (2010) finds no support for the hypothesis at all. Furthermore, contrary to the hypothesis, Hazelzet (2001) finds that the EU punishes former colonies of its member-states more harshly than it does other countries; however, the same states are also rewarded more than states that were not former colonies. Considering that almost all ACP-countries have been former colonies or protectorates of European countries the hypothesis is not sufficiently specified to be applied to the study of the human rights clause.

\section{Alternative Hypotheses}

Some contributions do explore alternative explanations. Portela (2007, p. 42, 2010, p. 144), for example, argues that the EU implements its human rights clause only when "it considers that it stands a reasonable chance of influencing the leadership responsible for the breaches". Portela points to how transitional authorities can perceive consultations as a benefit because it guarantees the continued flow of funds. This would also constitute a case of 'reasonable chance for influencing leadership' by the EU. Similarly, Laakso (2007, p. 125) states that "there is no willingness to use the instrument if prospects of its usefulness are low". Similarly, civil war and ongoing armed conflict have also been suggested as possible reasons for the nonimplementation of the human rights clause. Portela (2010) argues that the EU considers article 96 consultations to be redundant in cases where broader international efforts are in place. A notable exception to the interest-based perspectives described above is Del Biondo's (2011, 
2015a, 2015b) ${ }^{3}$ findings of a collision between concerns for democratisation and development. She argues that the so-called democratization-development dilemma can partially explain the absence of donor sanctions in for example Ethiopia and Rwanda. The EU is inclined prioritize stability in countries that performs well on development and thus avoid consultations on democratic issues. However, it remains unclear how these observations could be accounted for.

Summing up, two weaknesses can be discerned in the literature: First, there is a lack of explicit theoretical foundations. The majority of studies have been conducted without clarifying the theoretical assumptions underpinning their hypotheses. The implicit assumption is that actors calculate costs and benefits, and choose the best option accordingly. Furthermore, even when theory is used explicitly, it is rare that hypotheses other than ones based on self-interest are examined. The second weakness concerns methodology. When cases in which sanctions have been implemented are compared with the so-called non-cases, it becomes clear that only countries in which the existence of an "interest" of some sort is already known to exist have been tested empirically. Being qualitative case studies these contributions enhance our understanding of the EU's behaviour. However, the sum of the selection of cases results in a bias that does not allow for the hypotheses to be falsified.

\section{Redefining the population of cases}

In response to the weaknesses in the literature discussed above, I construct in the following a population of cases that can be used for future research on the human rights clause. This empirical groundwork is important because it may serve as a safeguard for the pitfall of operating with non-falsifiable hypotheses. The benefit of constructing this population of cases is that the process of selecting cases becomes more relevant. Avoiding a bias in the selection of cases in single studies, or becoming aware of a bias in the aggregation of many studies can

\footnotetext{
${ }^{3}$ See also Del Biondo and Orbie (2014)
} 
contribute to challenge some of the 'accepted truths' in the conditionality literature and open up to alternative explanations.

The method used to construct the population of cases was a systematic empirical tracing of the human rights clause's use and non-use by the EU towards ACP states the first twenty years of its existence 1995-2015. In total, 42 cases were identified. These comprise 24 cases in which the human rights clause was implemented and 18 (non-)cases where the clause could have been used but was not. I used data in the forms of official documents from the Council and the Commission, existing datasets on coups d'état, and election observation reports provided by international organizations (see below).

\section{Invoked Conditionality}

Table 1 lists the 24 instances in which official consultations were initiated by the EU in accordance with the terms of the human rights clause, together with the reason for the triggering of the consultations. In 15 of 24 cases, the clause was initiated due to the occurrence of a coup d'état, while in the remaining 8 cases consultations were initiated following a deterioration of the respect for democratic principles, human rights or the rule of law.

[Table 1 near here]

The data clearly show a tendency towards implementation of the clause in the event of a breach of democratic norms, with the occurrence of a coup d'état being the single most important trigger. The second most important reason is reported irregularities in elections. Human rights and good governance violations are sufficient to initiate the clause on only a few occasions. As has been pointed out in earlier studies on political conditionality, the pattern of implementation depicts a minimalist conception of democracy, with a focus on clear-cut breaches such as coups and electoral irregularities (Del Biondo, 2011; Tomaševski, 1997). Sharply defined breaches 
are regarded as being "easier" to respond to than breaches of human rights, where it is more difficult to decide where the "cut-off points" for reaction should be (Smith, 2001).

\section{The Non-Cases}

When identifying non-cases I have focused on breaches of democratic norms. I conducted an assessment of narrowly defined democratic quality, operationalized as electoral record and coup d'états, for all ACP states between 1995 and 2015. 7 cases in which the occurrence of a coup d'état was not followed by implementation of terms of the human rights clause were identified by a search in the Centre for Systemic Peace's dataset Coup d'état events 1946-2017 and cross-checked with the Conflict Barometer developed by the Heidelberg Institute for International Conflict Research ${ }^{5}$. In addition, I compiled a list of all elections that had taken place in ACP countries between 1995 and 2015 (224 elections), and conducted an examination and assessment of election reports, where these were available (156 reports). ${ }^{6}$ This resulted in the identification of 11 non-cases where there was no implementation of the human rights clause despite reports of major flaws in the electoral process according to the election observers. ${ }^{7}$ In addition, Côte d'Ivoire (2004) was added as a non-case because the Commission (2004) had proposed initiating consultations under Article 96 of the Cotonou Agreement owing to the deteriorating human rights situation in the country, but the Commission's proposal was not followed up by the Council. The 68 elections that were not monitored by an observer team were checked for reports of irregularities in Keesing's World News Archive, which did not result in

\footnotetext{
${ }^{4}$ http://www.systemicpeace.org/inscrdata.html

${ }^{5}$ https://www.hiik.de/en/konfliktbarometer/

${ }^{6}$ Accessed via ACE: http://aceproject.org/ero-en/index html?filter\&topic=\&country=\&type=Reports\%2 $\underline{\text { 0and } \% 20 \text { Assessments }}$

${ }^{7}$ In the assessment of the reports, elections were considered flawed if a report stated serious doubts about the result of the elections and/or that it had fallen short of key international standards.
} 
the identification of any new cases. ${ }^{8}$ Table 2 lists the 18 non-cases identified, classified according to the nature of the breach.

\section{[Table 2 near here]}

Two observations can be made based on the data. First, the picture presented here challenges the current consensus in the literature according to which the EU has acted coherently by initiating Article 96 consultations in all cases of a coup d'état in an ACP country (Crawford \& Kacarska, 2017; Del Biondo, 2011; Laakso et al., 2007, p. 49). Seven coups were not followed by an initiation of the procedures set out in the human rights clause. Second, as many as 11 cases can be identified in which flawed elections were not followed by implementation of the human rights clause. Previous studies had identified only a few such non-cases, which were usually countries with a relatively strong link to the EU based on development cooperation or trade - such as Ethiopia, Kenya and Nigeria. The systematic examination presented here, however, also pins down cases where no such strong link between the EU and the non-cases can be said to exist - such as Papua New Guinea and the Solomon Islands. Hence, it seems like interest-based explanations cannot fully account for the EU's human rights policy after all.

\section{Revisiting Core Concepts}

When we look at all of the cases identified the EU's implementation appears accidental. However, considering the extent of EU presence around the world, we must assume that the EU has proper monitoring mechanisms in place. Furthermore, instrumental variation is common in political organizations and we know that the Commission has several alternative

\footnotetext{
${ }^{8}$ The result of the 2014 legislative elections in Cook Islands were challenged due to high levels of corruption and electoral irregularities. This event was not counted as a non-case since the high court of Cook Island began hearings on the election process shortly after elections were held. The situation was resolved within the Cook Islands national institutions (see Keesing's p. 53476 and 53575).
} 
instruments at hand, for example conducting political dialogue or imposing an informal budget support aid cut. When the human rights clause fails to materialize perhaps it is because other instruments are being applied? There might also be certain situations where implementation of the clause would not be deemed legitimate or seen as useful. If these decisions are not random: how can they be accounted for? I will in what follows suggest some ways forward for studying why the human rights clause has been implemented in a seemingly inconsistent fashion.

Considering the normative aim of the conditionality policy, the possibility of norms influencing policies seems to be a particularly relevant hypothesis. When the EU introduces such a clause, making their aid and cooperation conditional on the respect for human rights abroad, we need a theoretical approach that makes it possible to take the EU's claims and policy seriously. Existing studies that have investigated the role of norms in the EU's decisions on aid sanctions seem to reject normative hypotheses once norms are found to be in conflict with interests. This may be due to the lack of applying perspectives that take norms equally seriously as interests. At least we need to consider the theoretical possibility that norm-based action can be prioritised over concerns for interests. Is there evidence to support that implementation has been conducted on the basis of norms? If so, which norms?

Among many, new institutionalist perspectives bring the influence of norms into focus. Following a "logic of appropriateness", actors make decisions linking particular situations to particular identities (March and Olsen, 1989). Actors evaluate what kind of action would be the "right thing to do" given what they see as being their own particular role. Thus, rather than calculating costs and benefits, actors are understood to be rule-followers with a capacity for evaluating what rule is appropriate in a given situation. A possible hypothesis, then, might be that the clear pattern of implementation of the human rights clause following clear-cut breaches such as coup d'états and electoral fraud has emerged as an informal rule of implementation. Likewise, one might hypothesize similar rules concerning non-implementation. If we are to 
believe Laakso (2007) and Portela (2007), for example, the clause is not implemented towards countries experiencing civil war - a finding that is more easily understood if actors are conceived of as rule-followers rather than utility-maximisers. Nonetheless, the adoption and implementation of the human rights clause is not a continuation of the member states' habits or policy. Rather it is the result of a deliberate choice by the EU. The human rights clause is also a novel tool in international relations thereby emphasising the probability of its implementation being made on rational decisions.

Instead of conceiving of actors in ways that ascribe to them a predetermined set of preferences, a communicative perspective hypothesizes that actors are able to reach agreements through the use of dialogue and arguments. But, how does this translate to a hypothesis about the decision to initiate the human rights clause? First, hypotheses based on this perspective rest on different assumptions than the rationalist paradigm of power and national interest. Rather than maximising self-interest, acting according to normative expectations or assessments would be considered to be rational action. It is through communicative processes that norms are scrutinized, and their relevance and binding character rationally assessed (Sjursen, 2004). It is thus necessary to take the power of words and arguments seriously. The EU's conditionality policy puts considerable emphasis on political dialogue and consultations. Following a breach, offenders are asked to give reasons for their failure to comply with their obligations. On the basis of the reasons put forward to justify the breach, the other party can make a distinction between compliance and non-compliance. Depending on their validity, the arguments presented may be an important factor in the decision as to whether to respond with hard sanctions, to implement the human rights clause or to continue an already on-going political dialogue. One hypothesis could be tied such communicative processes. One would have to look at indicators such as the arguments presented by the respective partners in the dialogue and the justification by the EU of the particular instrument used in each case. Second, a communicative perspective 
is based on a different conception of power. Instead of only understanding power in materialist terms, this conception equals power to legitimacy. An actor will not have power in the long run if it does not have legitimacy. One could derive a second hypothesis assuming that the EU seeks legitimacy in its human rights policy. Then, we would expect the EU to prefer to take part in broader international efforts rather than acting on its own through the human rights clause or a sanction. Furthermore, the EU would be more likely to react if it finds broad support in civil society in the respective country or internationally. Third, a communicative perspective open up to actors considering several norms at the same time. One could hypothesize that the lack of implementing the human rights clause in a certain case is a consequence of policy-makers following a different but competing norm. One indicator for this hypothesis could be that a country that successfully manages to hold free and fair elections is not sanctioned for a human rights breach because it is considered to have contradictory effect on the democratic achievements made. Considering that some literature has found empirical evidence of a dilemma between donors concerns for democracy and for development, such a hypothesis might prove particularly relevant for further research on the EU's conditionality policy (del Biondo 2015a, b).

\section{Conclusion}

In the international system, legal procedures for protecting human rights are still weak. There are few signs of change to this. Emerging and rising powers such as China view the international enforcement of human rights a limit to national autonomy and seeks to limit legal procedures for protecting human rights rather than strengthening them. The EU's human rights clause is a unique exception. Articles 9, 96 and 97 of the Cotonou agreement constitute the most comprehensive legal commitment to respecting human rights and democracy in an international agreement. Yet, recurrent claims of selective and inconsistent implementation of the human rights clause questions the legitimacy basis of the Union's human rights policy. If the EU's 
actions does not match its rhetoric, it runs the risk of being accused of hypocrisy. Such inconsistencies might be particularly problematic for an actor such as the EU. According to Raube and Tonra (this volume) the EU relies to a greater relative degree on the legitimacy of its actions. In nation states patterns of authority and order are well understood and acknowledged by internal and external actors. At the EU level the 'legitimacy of authority and order' is less clear. This claim corresponds with Sjursen's (this volume) finding that the EU's internal legitimacy is 'quite weak': its foreign policy falls short of the democratic requirements of autonomy and accountability. Hence, claims of inconsistent behaviour and double standards questions the aspect of the EU's foreign policy that possibly holds the strongest claim to legitimacy, namely its actions.

This article contributes to the debate regarding the extent to which the EU has delivered on its human rights commitments, more concretely if the EU's policy is as inconsistent as the scholarly literature claims. I have done so by emphasising the tools we use to analyse the EU's actions. In this article I show that the literature on the EU's practices are based on biased empirical foundations. A systematic assessment shows that a number of cases remain unexplored. Both strategically important and non-important states have been exempted from consultations in the aftermath of a breach of the essential elements of the conditionality clause. In previous studies, only strategically important states such as Ethiopia and Nigeria have been used as examples, resulting in existing claims becoming self-fulfilling prophecies: the hypotheses are only tested against cases where it is already known that interests exist. What this empirical investigation shows is that consistent claims of hypocrisy and double standards might be over-emphasised in the literature and that it is necessary to investigate hypotheses other than those based on self-interest to fully account for the EU's human rights policy.

\section{Acknowledgements}

I would like to thank... 


\section{References}

Alesina, A. \& Dollar, D. (2000). Who gives foreign aid to whom and why? Journal of Economic Growth, 5(1), 33-63.

Arts, K. (2000). Integrating human rights into development cooperation: The case of the Lomé convention, The Hague: Kluwer Law International.

Brüne, S. (2007). Testfall ãthiopien. In: A. Jünemann \& M. Knodt (Eds.) Externe demokratieforderung durch die Europäische Union (pp. 53-70) . Baden-Baden: Nomos.

Council (1995, November, 20). Common position of 20 November 1995 defined by the Council on the basis of Article J.2 of the Treaty on European Union, on Nigeria [Common position]. Retreived from http://eur-lex.europa.eu/LexUriServ/LexUriServ.do?uri=CELEX :31995E0515:EN:NOT.

Council (1999, May, 17). Council Decision of 17 May 1999 repealing Common Position 98/614/CFSP concerning Nigeria (1999/347/CFSP)[Decision]. Retreived from http://eurlex.europa.eu/LexUriServ/LexUriServ.do?uri=CELEX:31999D0347:EN:HTML.

Commission (2004, August, 10). Commission proposes consultations with Côte d'Ivoire on human rights, democracy and rule of law [Press release]. Retreived from http://europa.eu/ rapid/press-release_IP-04-1023_en.htm?locale=en

Crawford, G. (1997). Foreign aid and political conditionality: Issues of effectiveness and consistency. Democratization, 4(3), 69-108.

Crawford, G. (2000). Foreign aid and political reform: A comparative analysis of democracy assistance and political conditionality, Basingstoke: Palgrave Mcmillan.

Crawford, G. \& S. Kacarska (2017). Aid sanctions and political conditionality: Continuity and change. Journal of International Relations and Development, online first.

Del Biondo, K. (2011). EU aid conditionality in ACP countries: Explaining inconsistency in EU sanctions practice. Journal of Contemporary European Reseach, 7(3), 380-395. 
Del Biondo, K. (2015a). Norms or interests? Explaining instrumental variation in EU democracy promotion in Africa. Journal of Common Market Studies, 53(2), 237-254.

Del Biondo, K. (2015b). Donor interests or development performance? Explaining sanctions in EU democracy promotion in sub-Saharan Africa, World Development 75(November), 74-84.

Del Biondo, K. \& J. Orbie (2014) The European Commission's implementation of budget support and the governance incentive tranche in Ethiopia: Democracy promoter or developmental donor? Third World Quarterly, 35(3), 411-427.

EPC Bulletin (1993). 93/305. Statement on Nigeria [Press release]. Retreived from http://aei.pitt.edu/view/eusubjects/H002006001.html.

Feliu, L. (2003). A two-level game: Spain and the promotion of democracy and human rights in Morocco, Mediterranean Politics, 8(2-3), 90-111.

Fierro, E. (2003). The EU's approach to human rights conditionality in practice, The Hague: Kluwer Law International.

Fioramonti, L. \& A. Poletti (2008). Facing the giant: Southern perspectives on the European Union, Third World Quarterly, 29(1), 167-180,

Hazelzet, H. (2001). Carrots or Sticks? EU and US reactions to human rights violations (1989-2000) (Doctoral dissertation). Available from Cadmus, EUI Research Reopsitory.

Hyde-Price, A. (2008). A 'tragic actor'? A realist perspective on 'ethical power Europe', International Affairs, 84(1), 29-44.

Jünemann, A. \& Knodt, M. (2007). European external democracy promotion, Baden-Baden: Nomos.

Laakso, L. (2007). Politics and partnership in the Cotonou agreement. In: J. Gould \& L. Siitonen (Eds.) Anomalies of aid: a festschrift for Juhani Koponene (pp.116-141). Helsinki: University of Helsinki, Institute for Development Studies. 
Laakso, L., T. Kivimaki, \& M. Seppanen (2007). Evaluation of coordination and coherence in the application of article 96 of the Cotonou partnership agreement. Studies in European Developmen t Co-operation Evaluation no 6. Brussels: European Union.

March, J. G. \& J. P. Olsen (1989). Rediscovering institutions: The organizational basis of politics, New York: Free Press.

Mearsheimer, J. J. (2005). E. H. Carr vs idealism: The battle rages on, International Relations, 19(2), 139-52.

Meyer, C. (2010, April, 2).Uranium Mining in Niger. Retrieved from: www.spiegel.de/international/world/uranium-mining-in-niger-tuareg-activist-takes-onfrench-nuclear-company-a-686774.html

Meyer-Resende, M. (2008). EU election observation. Achievements, challenges. Brussels: Directorate-General for External Policies of the Union.

Olsen, G. R. (1998). Europe and the promotion of democracy in post cold war Africa: How serious is Europe and for what reason? African Affairs, 97(388), 343-367.

Olsen, G. R. (2000). Promotion of democracy as a foriegn policy instrument of 'Europe': Limits to international idealism, Democratization, 7(2), 142-167.

Olsen, G. R. (2002a). The European Union: An ad hoc policy with a low priority. In: P. J. Schraeder (Ed.) Exporting democracy. Rethoric vs. realtiy (pp.131-145). Boulder: Lynne Rienner Publishers.

Olsen, G. R. (2002b). Promoting democracy, preventing conflict: The European Union and Africa, International Politics, 39(September), 311-328.

Portela, C. (2007). Aid suspensions as coercive tools? The European Union's experience in the African-Caribbean-Pacific (ACP) context, Review of Russian Affairs, 3(2), 38-53.

Portela, C. (2010). European Union sanctions and foreign policy. London: Routledge.

Santiso, C. (2003). Responding to democratic decay and crises of governance: The European Union and the convention of Cotonou, Democratization, 10(3), 148-172. 
Schimmelfennig, F. (2001). The community trap: Liberal norms, rhetorical action, and the eastern enlargement of the European Union, International Organization, 55(1), 47-80.

Sjursen, H. (2004). Changes to European security in a communicative perspective. Cooperation and Conflict, 39(2), 107-128.

Smith, K. E. (1998). The use of political conditionality in the EU's relations with third countries: How effective? European Foreign Affairs Review, 3(2), 253-274.

Smith, K. E. (2001). The EU, human rights and relations with third countries: 'foreign policy' with an ethical dimension? In: K. E. Smith \& M. Light (Eds.) Ethics and foreign policy (pp.185-204). Cambridge: Cambridge University Press.

Stokke, O. (1995). Aid and political conditionality. London: Frank Cass.

Tomaševski, K. (1997). Between sanctions and elections: aid donors and their human rights performance. London: Pinter.

Uvin, P. (2004). Human rights and development. Bloomfield, CT: Kumarian Press.

Warkotsch, A. (2010). Realpolitik and international sanctions to non-compliance with liberal democratic norms: Comparing EU and US respons patterns. Cooperation and Conflict, 45(1), 80-106. 
Table 1. Implementation of the human rights clause in ACP countries 9

\begin{tabular}{|c|c|c|c|c|}
\hline Year, Country & Coup d'état & Flawed elections & Human rights & Rule of law \\
\hline 2015 Burundi & & $\mathrm{X}$ & $\mathrm{X}$ & $\mathrm{X}$ \\
\hline 2011 Guinea-Bissau & & & $\mathrm{X}$ & $\mathrm{X}$ \\
\hline 2010 Niger & $\mathrm{X}$ & & & \\
\hline 2009 Niger & & $\mathrm{X}$ & & \\
\hline 2009 Madagascar & $\mathrm{X}$ & & & \\
\hline 2009 Guinea & $\mathrm{X}$ & & & \\
\hline 2008 Mauritania & $\mathrm{X}$ & & & \\
\hline 2007 Fiji & $\mathrm{X}$ & & & \\
\hline 2005 Mauritania & $\mathrm{X}$ & & & \\
\hline 2004 Guinea & & $\mathrm{X}$ & & \\
\hline 2004 Togo & $\mathrm{X}$ & $\mathrm{X}$ & $\mathrm{X}$ & \\
\hline 2003 Guinea-Bissau & $\mathrm{X}$ & & & \\
\hline 2003 Central African Republic & $\mathrm{X}$ & & & \\
\hline 2001 Zimbabwe & & $\mathrm{X}$ & $\mathrm{X}$ & $\mathrm{X}$ \\
\hline 2001 Liberia & & $\mathrm{X}$ & $\mathrm{X}$ & $\mathrm{X}$ \\
\hline 2001 Côte d'Ivoire & & $\mathrm{X}$ & & \\
\hline 2000 Fiji & $\mathrm{X}$ & & & \\
\hline 2000 Haiti & & $\mathrm{X}$ & & \\
\hline 2000 Côte d'Ivoire & $\mathrm{X}$ & & & \\
\hline 1999 Guinea-Bissau & $\mathrm{X}$ & & & \\
\hline 1999 Comoros & $\mathrm{X}$ & & & \\
\hline 1999 Niger & $\mathrm{X}$ & & & \\
\hline 1998 Togo & & $\mathrm{X}$ & & \\
\hline 1996 Niger & $\mathrm{X}$ & & & \\
\hline
\end{tabular}

\footnotetext{
${ }^{9}$ The cases were identified by a systematic search at the website of the Council (www.consilium.europa.eu). The search term used was 'Article 96' and 'Article 366a'
} 
Table 2. Identified breaches, not subject to the human rights clause

\begin{tabular}{|c|c|c|c|c|}
\hline Year, Country & Coup d'état & Flawed elections & Human rights & Rule of law \\
\hline 2014 Burkina Faso & $X$ & & & \\
\hline 2012 Mali & $\mathrm{X}$ & & & \\
\hline 2010 Côte d'Ivoire & & $\mathrm{X}$ & & \\
\hline 2007 Nigeria & & $\mathrm{X}$ & & \\
\hline 2007 Kenya & & $\mathrm{X}$ & $\mathrm{X}$ & \\
\hline 2005 Ethiopia & & $\mathrm{X}$ & $\mathrm{X}$ & \\
\hline 2004 Côte d'Ivoire & & $\mathrm{X}$ & $\mathrm{X}$ & $\mathrm{X}$ \\
\hline 2003 Nigeria & & $\mathrm{X}$ & & \\
\hline 2002 Papua New Guinea & & $\mathrm{X}$ & & \\
\hline 2002 Equatorial Guinea & & $\mathrm{X}$ & & \\
\hline 2000 Solomon Islands & $\mathrm{X}$ & & & \\
\hline 2001 Chad & & $\mathrm{X}$ & & \\
\hline 2000 Mauritania & & $\mathrm{X}$ & & \\
\hline 2000 Tanzania & & $\mathrm{X}$ & $\mathrm{X}$ & \\
\hline 1997 Sierra Leone & $\mathrm{X}$ & & & \\
\hline 1997 Congo-Brazzaville & $\mathrm{X}$ & & & \\
\hline 1996 Burundi & $\mathrm{X}$ & & & \\
\hline 1996 Sierra Leone & $\mathrm{X}$ & & & \\
\hline
\end{tabular}

